\title{
iPSCs as a Platform for Disease Modeling, Drug Screening, and Personalized Therapy in Muscular Dystrophies
}

\author{
Jose L. Ortiz-Vitali 1 and Radbod Darabi * \\ Center for Stem Cell and Regenerative Medicine (CSCRM), The Brown Foundation Institute of Molecular \\ Medicine for the Prevention of Human Diseases (IMM), The University of Texas Health Science Center at \\ Houston, Houston, TX 77030, USA; Jose.L.OrtizVitali@uth.tmc.edu \\ * Correspondence: Radbod.Darabi@uth.tmc.edu; Tel.: +1-(713)-500-3411; Fax: +1-(713)-500-2424
}

Received: 6 November 2018; Accepted: 26 December 2018; Published: 3 January 2019

check for updates

\begin{abstract}
Induced pluripotent stem cells (iPSCs) are the foundation of modern stem cell-based regenerative medicine, especially in the case of degenerative disorders, such as muscular dystrophies (MDs). Since their introduction in 2006, many studies have used iPSCs for disease modeling and identification of involved mechanisms, drug screening, as well as gene correction studies. In the case of muscular dystrophies, these studies commenced in 2008 and continue to address important issues, such as defining the main pathologic mechanisms in different types of MDs, drug screening to improve skeletal/cardiac muscle cell survival and to slow down disease progression, and evaluation of the efficiency of different gene correction approaches, such as exon skipping, Transcription activator-like effector nucleases (TALENs), Zinc finger nucleases (ZFNs) and RNA-guided endonuclease Cas9 (CRISPR/Cas9). In the current short review, we have summarized chronological progress of these studies and their key findings along with a perspective on the future road to successful iPSC-based cell therapy for MDs and the potential hurdles in this field.
\end{abstract}

Keywords: iPSCs; muscular dystrophies; DMD; duchenne; gene correction; CRISPR/Cas9; stem cells

\section{Introduction}

Since 2006, and with the generation of induced pluripotent stem cells (iPSCs) [1-3], the field of stem cell biology and regenerative medicine has developed a more optimistic outlook to providing personalized patient therapy using stem cells. Due to their patient-specific nature and ease of generation, iPSCs are a great candidate for disease modeling, drug screening, and gene correction. iPSCs also carry other major advantages, such as reduced ethical concern (unlike embryonic stem cells (ESCs)), the ability to give rise to every cell type (pluripotency), and better immunocompatibility since they are harvested and reprogrammed from the same patient [4-6]. Initially, iPSCs were derived via integrating viral vectors that delivered the key transcription factors Klf4, Oct3/4, Sox2, Lin-28, and c-Myc [1-3,7], but this posed a concern for downstream therapeutic use due to unforeseen insertional mutagenesis caused by viral genome integration. To overcome this problem, new methods were developed, such as non-integrating viral (Sendai virus) and non-viral methods (cDNA, mRNA, protein) that are much safer than the traditional method, and alleviate the risk of insertional mutagenesis [8-13]. These advances, in conjunction with the possibility of the generation of tissue-specific cells from iPSCs and new gene correction techniques, such as TALENs $[14,15]$ and CRISPR/Cas9 [16,17], create great hopes for personalized stem cell therapy to become a reality for treating countless degenerative disorders.

One such group of disorders that would benefit from iPSC-based personalized therapy are the muscular dystrophies (MDs). MDs are a heterogeneous group of degenerative skeletal muscle disorders 
caused by a variety of genetic defects that lead to progressive muscle wasting, formation of fibrotic and adipose tissue in the muscle, and even death in severe cases due to cardiomyopathy and respiratory failure [18-20]. There are many types of MDs with various degrees of severity, such as Becker (BMD), myotonic, limb girdle (LGMD), and the most well-known, Duchenne Muscular Dystrophy (DMD). While mild to moderate MDs become symptomatic at young or middle age with manageable complications, severe types, unfortunately, can be fatal [18-21]. An example of a severe type of muscular dystrophy is Duchenne Muscular Dystrophy (DMD), which occurs primarily in males between three and five years old and leads to progressive muscle wasting and atrophy $[18,21,22]$. By the teenage years, these patients are limited to wheelchairs and suffer from severe respiratory and cardiac problems. Unfortunately, to date, there is no definitive cure for MDs and treatment is limited to the management of complications by surgery and medical care for cardiac and respiratory complications [18-20]. Because iPSC and gene editing bringing new hope for the treatment of muscular dystrophies, we have overviewed the chronological development of promising advances (see Supplementary Figure S1) using the technologies for MD disease modeling and gene correction. We point out major caveats and give future directions.

\section{2. iPSCs and Disease Modeling for Muscular Dystrophies}

Many animal models, such as mouse, pig, and dog, are currently available to study the biology of MDs, in particular for DMD [23-25]. However, they can fall short of the recapitulation of disease pathology and phenotype due to the variability of biochemical abnormalities and compensatory mechanisms in different species. While dog and pig models prove to be useful DMD animal models by providing clinically relevant data, gestation periods are considerably longer. Further, the animals require much larger spaces to house. Both of these are factors lead to the limitation of the power of significance and greater expense [26]. On the other hand, while mice models do not have these problems, it is still difficult to extrapolate mice data to DMD patients due to the presence of compensatory mechanisms and milder phenotypes (such as $m d x$ mice).

In contrast, iPSCs provide an optimal tool for fast expansion and creation of tissue-specific cells to model diseases in vitro. These patient-specific cells can be used for a variety of purposes including drug screening, in vitro analysis of true myogenic capacity, and disease pathology before the onset of the typical secondary effects of inflammation. As seen in modeling, a disease-affected cell type with iPSCs also facilitates testing parameters, such as myoblasts derived from DMD patients or animal models, drug toxicity, dose-response, and efficacy on the target. In addition, mice or other animal models may not capture the true genetic variation of the human population (in-breeding) or simply have different phenotypes in muscle stem cells' behavior and regeneration due to their different genetic background [27]. iPSCs derived in a patient-specific manner, however, bypass this issue and maintain as close a model as possible to the true genetic nature of the human population. Therefore, the skeletal muscle field began to use iPSCs for disease modeling soon after the development of iPSC reprogramming in 2007 (listed in Table 1). 
Table 1. List of key studies using Induced pluripotent stem cells (iPSCs) for disease modeling in case of muscular dystrophies.

\begin{tabular}{|c|c|c|c|c|c|}
\hline Disease Type & Cell Type & Methodology & Purpose & Year & Reference \\
\hline $\mathrm{DMD} / \mathrm{BMD}$ & iPSC-human & Retroviral transduction of iPSC inducing factors & Myogenic potential of DMD/BMD iPSCs. & 2008 & Park et al. [28] \\
\hline $\begin{array}{l}\mathrm{DMD} / m d x \\
\text { mice }\end{array}$ & iPSC-mice & $\begin{array}{c}\text { Myogenic differentiation of murine iPSCs using gene } \\
\text { over-expression }\end{array}$ & Testing in vivo engraftment potential & 2011 & Darabi et al. [29] \\
\hline $\begin{array}{l}\mathrm{DMD} / \mathrm{NSG}- \\
m d x^{4 \mathrm{Cv}}\end{array}$ & ES/iPSC-human & $\begin{array}{l}\text { Gene Over-expression. TA injection of hES/iPSC in } \\
\text { NSG- } m d x{ }^{4 C v} \text { mice }\end{array}$ & Functional restoration of dystrophin in $m d x$ mice. & 2012 & Darabi et al. [30] \\
\hline LGMD2D & iPSC-human & $\begin{array}{l}\text { Retroviral transduction of fibroblast to iPSC and inducible } \\
\text { MyoD expression. IM injection of cells }\end{array}$ & $\begin{array}{l}\text { In vivo transplantation of corrected iPSC gave rise } \\
\text { to striated a-sarcoglycan }{ }^{+} \text {fibers }\end{array}$ & 2012 & Tedesco et al. [31] \\
\hline FSHD & iPSC-human & $\begin{array}{c}\text { Retroviral transduction of iPSC factors and EB } \\
\text { differentiation }\end{array}$ & $\begin{array}{l}\text { Role of DUX4 in myogenic inhibition and neural } \\
\text { induction }\end{array}$ & 2010 & Snider et al. [32] \\
\hline DM1 & iPSC-human & iPSC generation and evaluation of CTG-CAG repeat length & $\begin{array}{c}\text { Mechanism of CTG-CAG repeat in 3'UTR of } \\
\text { DMPK1 gene }\end{array}$ & 2013 & Du et al. [33] \\
\hline DMD & iPSC-human & $\begin{array}{l}\text { Transfection of Doxycycline inducible } \mathrm{MyoD} \text { plasmid. } \\
\text { Electrical stimulation and fluorescent } \mathrm{Ca}^{2+} \text { marker to } \\
\text { visualize influx }\end{array}$ & $\begin{array}{l}\text { Reversal in abnormality of } \mathrm{Ca}^{2+} \text { ion influx } \\
\text { following dystrophin restoration }\end{array}$ & 2015 & Shoji et al. [34] \\
\hline DMD & iPSC-human & $\begin{array}{l}\text { Patient-derived DMD iPSC generation. Electrophysical } \\
\text { recording and } \mathrm{Ca}^{2+} \text { transients images with CMOS camera }\end{array}$ & Pathologic features of cardiomyopathy & 2015 & Lin et al. [35] \\
\hline LGMD & iPSC-human & $\begin{array}{l}\text { iPSC generated and patch clamp performed for ion currents } \\
\text { and } \mathrm{Ca}^{2+} \text { transients measured via fluorescence }\end{array}$ & $\begin{array}{l}\text { Abnormalities and pathologic features in ion } \\
\text { channel function in patient iPSC-derived } \\
\text { cardiomyocytes }\end{array}$ & 2018 & El-Battrawy et al. [36] \\
\hline DMD & iPSC-human & DMD iPSC corrected with DYSTROPHIN-HAC transfection & $\begin{array}{l}\text { Variations in disease related phenotypes between } \\
\text { DMD patients }\end{array}$ & 2016 & Choi et al. [37] \\
\hline $\begin{array}{l}\text { DMD/LGMD } \\
\text { BMD }\end{array}$ & iPSC-human & $\begin{array}{l}\text { 3D matrix differentiation to observe myofibers formation. } \\
\text { Triple lineage constructs created with } 70 \% \text { myogenic cells } \\
\text { and 30\% vascular }\end{array}$ & $\begin{array}{l}\text { Development of 3D hydrogel platform for muscle } \\
\text { stem cell and myofibers formation }\end{array}$ & 2018 & Maffioletti et al. [38] \\
\hline DMD & iPSC-human & $\begin{array}{l}\text { Cells cultured on culture substrated with nanogrooves } \\
\text { coated with Matrigel or Laminin to observe myotube } \\
\text { alignment with and without DAPC-Laminin interaction. }\end{array}$ & $\begin{array}{l}\text { Myotube alignment and orientation in } \\
\text { microenvironment and importance of DAPC }\end{array}$ & 2018 & Xu et al. [39] \\
\hline
\end{tabular}


Initial reports in 2008 and later were mainly focused on the generation of iPSCs from MDs (such as DMD and LGMD) and proof of concept for their myogenic differentiation [28-31]. After this step, subsequent studies used iPSCs for disease modeling and evaluation of pathophysiology in muscular dystrophies such as Facioscapulohumeral muscular dystrophy (FSHD), myotonic dystrophy, and DMD [32-34]. These are typical examples of using iPSCs to model the disease and identify pathologic features or etiologies. The first study successfully proved the pathologic role of DUX4 in inhibition of mesoderm induction and its potential role as a neural-inducing factor, and as a potential contributing factor to FSHD pathology [32]. The second study used iPSCs from myotonic dystrophy type 1 (DM1) and demonstrated involved mechanisms in CTG.CAG triplet repeat expansion in the $3^{\prime}$ untranslated region of the DMPK1 gene in patient iPSCs [33]. In the third study, DMD iPSC-derived myotubes were used to study the abnormalities in calcium ion influx following electric stimulation and their reversal after dystrophin restoration, which is a classic example of iPSC disease modeling in the case of muscular dystrophies [34].

The iPSCs have also been used to model and study the mechanisms of dilated cardiomyopathy in DMD patients [35]. DMD iPSC-derived cardiomyocytes demonstrated major phenotypic and pathologic features of dilated cardiomyopathy, such as elevated levels of resting calcium, mitochondrial damage, and cell apoptosis. A similar study also used iPSCs from LGMD patients to study ion channel dysfunction in cardiomyocytes derived from patient iPSCs and successfully demonstrated the presence of its pathologic features, such as abnormal action potentials, differences in peak and late ion currents, and significant reduction of systolic and diastolic intracellular calcium concentrations [36].

Another interesting study has recently used DMD-iPSCs from patients with different dystrophin mutations to study variations in disease phenotype [37]. Using a directed differentiation approach for myogenic induction in iPSCs, derived myoblasts demonstrated typical disease-related phenotypes with patient-to-patient variability. These included variations in inflammatory response genes, increased $\mathrm{BMP} / \mathrm{TGF}-\beta$ signaling, and reduced fusion potential of myotubes from different patients. Another example of using iPSCs for modeling muscular dystrophy is the recent report of the generation of a 3D platform using hydrogels to provide the right niche for proper muscle stem cell and myofiber development, as well as modeling skeletal muscle laminopathies and their pathologic features, such as nuclear abnormalities [38]. Finally, a recent study has used the DMD-iPSC-derived myotubes to study myotube alignment and orientation in the cell microenvironment and demonstrated the importance of Dystrophin-Associated-Protein-Complex (DAPC) in proper cell alignment through its interaction with laminin [39]. Overall, these efforts have so far been able to clearly demonstrate the great potential of iPSCs for disease modeling in the case of various types of MDs, as well as helping to identify new pathologic mechanisms involved in these disorders.

\section{3. iPSCs and Drug Screen for Muscular Dystrophies}

Since drug screening and development has been mostly dependent on animal models and immortalized cell lines, iPSC disease models now provide a unique human/patient platform. iPSC based-disease models can be generated in a patient-specific manner and will potentially be useful in the identification of involved pathologies as well as in developing new treatments for MDs. In addition, patient-specific iPSC drug screening not only allows for the study of disease pathways but also when paired with in vivo models and can allow for testing of the safety and efficacy of the new drug candidate.

Although the application of iPSCs for drug screening started in early 2009 with the modeling of cardiac arrhythmias [40], in the case of muscular dystrophies it was delayed until a few years later (listed in Table 2). One major reason for this delay might be due to difficulties in myogenic differentiation and expansion, which with the availability of recent methods, will be overcome in the near future [41,42].

The first report of using iPSCs for drug screening in MDs was published in 2014 when a team of investigators generated 16 iPSC lines from patients with Duchenne and Becker muscular 
dystrophies (DMD, BMD) [43]. This was done by utilizing in vitro myogenic induction using MyoD over-expression, and the effects of two hypertrophic proteins, IGF-1 and Wnt7a, were evaluated on patient iPSC-derived myogenic cells. The results indicated the effectiveness of both agents in inducing significant muscle hypertrophy in iPSC-derived myotubes from the patients. The results supported their potential application as a pharmacologic treatment in muscular dystrophies [43]. Later, in 2015, DMD-iPSC-derived cardiomyocytes (CMs) were used for modeling dilated cardiomyopathy and the efficacy of a membrane sealant, Poloxamer 188, was evaluated on the cells [35]. The results indicated a significant reduction in the resting cytosolic calcium level along with reduced caspase-3 (CASP3) activation and apoptosis in DMD iPSC-CMs, indicating the potential therapeutic benefit of this agent [35]. In another study, the effect of a nitric oxide donor and ATP-Sensitive Potassium Channel Opener, Nicorandil, was evaluated in DMD iPSC-CMs [44]. As DMD cardiomyocytes generally suffer from decreased levels of endothelial and neuronal nitric oxide synthases, they are more susceptible to cell injury and cell death after stress due to increased levels of reactive oxygen species (ROS) and dissipation of the mitochondrial membrane potential [44]. This iPSC-based screen confirmed the protective effect of Nicorandil through nitric oxide-cyclic guanosine monophosphate pathway and mitochondrial adenosine triphosphate-sensitive potassium channels. Interestingly, when used in isolated hearts of $m d x$ mice (a mouse model for DMD), Nicorandil was able to improve the overall cardiac function [44], thus, indicating its potential cardioprotective effect as a therapeutic agent for the treatment of cardiomyopathy in MDs.

To facilitate drug screening for MDs, another recent study has adapted the myogenic differentiation of human iPSCs in a 384-well format with uniform and high myotube differentiation efficiency, which makes it very favorable for high-throughput drug screening (HTS) [45]. Finally, another interesting study has recently used the myotonic dystrophy DM1-iPSCs to model the disease and use antisense oligonucleotide treatment screen. The results indicated the effectiveness of the antisense oligonucleotide by abolishing RNA foci and rescuing BIN1 mis-splicing in DM1 iPS cell-derived myotubes [46]. Overall, these limited reports indicate the feasibility and usefulness of iPSCs for drug screening in the case of MDs and provide basic guidelines and protocols toward the development of HTS for myopathies using patient iPS cells. Of course, as mentioned above, any candidate for HTS in iPSC screening should be further validated for in vivo safety and efficacy using appropriate animal models. 
Table 2. List of key studies using iPSCs for drug screening in case of muscular dystrophies.

\begin{tabular}{|c|c|c|c|c|}
\hline Type of Model & Purpose & Method of Development & Year & Reference \\
\hline iPSC DMD/BMD & $\begin{array}{l}\text { Induction of muscle hypertrophy in } \\
\text { iPSC-derived myotubes. } \\
\text { Validation of pharmacologic treatment in MDs }\end{array}$ & $\begin{array}{l}\text { In vitro myogenic induction: } \\
\text { overexpressed MyoD and evaluated the } \\
\text { effect on IGF-1 and Wnt7a in patient iPSCs }\end{array}$ & 2014 & Abujarour et al. [43] \\
\hline iPSC-DMD & $\begin{array}{l}\text { Modeling dilated cardiomyopathy and efficacy } \\
\text { of membrane sealant Poloxamer } 188 \\
\text { Confirm protective effect of Nicorandil in } m d x \\
\text { mice as cardioprotective agent }\end{array}$ & $\begin{array}{l}\text { Directed differentiation on feeder MEF } \\
\text { cells. Electrophysiological recording } \\
\text { performed as well as } \mathrm{Ca}^{2+} \text { transients } \\
\text { imaged with CMOS camera }\end{array}$ & 2015 & Lin et al. [35] \\
\hline iPSC-DMD & HTS in 384-well format for drug screening & $\begin{array}{l}\text { Directed differentiation and MyoD } \\
\text { induction via various methods including } \\
\text { re-plating technique, feeder MEF cells, and } \\
\text { feeder-free adapted }\end{array}$ & 2017 & Uchimura et al. [45] \\
\hline iPSC-DM1 & $\begin{array}{l}\text { To model DM1 and evaluate effectiveness of } \\
\text { oligonucleotide treatment }\end{array}$ & $\begin{array}{l}\text { Inducible Pax7 cell line for differentiation } \\
\text { to skeletal muscle }\end{array}$ & 2018 & Mondragon-Gonzalez et al. [46] \\
\hline
\end{tabular}




\section{4. iPSCs and Gene Correction for Muscular Dystrophies}

With a lack of effective therapy for muscular dystrophies, gene-based therapies combined with iPSC technology provide an attractive approach to treatment. Therefore, multiple efforts have been made so far to validate the efficacy of gene correction strategies on iPSCs derived from MD patients (listed in Table 3). One of the initial reports using this strategy was done in 2010 through the application of a human artificial chromosome (HAC) carrying the complete genomic dystrophin sequence (DYS-HAC) [47]. After the generation of DMD-iPSCs, the vector was transferred to the cells via microcell-mediated chromosome transfer (MMCT). As proof of principle, tissue-specific expression of dystrophin was evaluated and confirmed in muscle tissues, as well as its proper expression in chimeric mice [47]. This was the pioneering report of gene correction in iPSCs in the case of muscular dystrophies.

Another popular approach for gene correction in the case of DMD involves application of exon-skipping to reconstitute a truncated form of the dystrophin gene. This employs an antisense oligonucleotide (AON) that binds to the mutation site in mRNA and induces exon-skipping, thus, allowing partial restoration of the reading frame. One example of this approach is the work undertaken in 2013 using exon-skipping to restore dystrophin expression in human DMD iPSC-derived cardiomyocytes [48]. Using seven different DMD iPSCs harboring various mutations across the DMD gene, an antisense oligonucleotide-mediated skipping of exon 51 was able to restore the dystrophin expression to nearly $30 \%$ of the normal level, thus, proving the relative efficiency of this strategy [48]. At the same time, another ex vivo gene therapy approach was developed with the delivery of the micro-utrophin $(\mu \mathrm{UTRN})$ using the highly efficient "sleeping beauty" transposon system for gene transfer and stable gene expression [49]. In this study, dKO-iPSCs (from dKO mice, a double-knockout mouse model for dystrophin and utrophin with a severe dystrophic phenotype similar to DMD patients) were corrected, and the expression of the transgene was evaluated in vitro as well as in vivo after transplantation into the dystrophic mice. Engrafted cells were able to express high levels of micro-utrophin, along with muscle stem cell engraftment and functional improvement in muscle contractility [49].

The next advancement to this field was the use of site-specific gene editing technologies for correction of the mutations. A classic example of this approach is through the application of Transcription activator-like effector nucleases (TALENs) and RNA-guided endonuclease Cas9 (CRISPR/Cas9) for gene correction in DMD iPSCs, which was reported in 2015 [50]. By comparing three different corrections strategies (exon-skipping, frame-shifting, and exon knockin) in DMD-iPSCs, the efficacy of each approach was evaluated. Results indicated similar efficacy of TALEN and CRISPR/Cas9 for targeting, and superiority of exon knockin for the restoration of dystrophin when compared to exon-skipping and frame-shifting [50]. This work also proved the efficacy of programmable nucleases for gene correction in iPSCs from muscular dystrophy/DMD patients. Another interesting study in 2016 designed a single CRISPR/Cas9 deletion strategy that can target a majority of DMD patient mutations (60\%) [51]. This strategy includes deletion and Non-homologous end joining (NHEJ) of the DMD gene around its common mutation hotspot to reframe the gene. Corrected DMD iPSCs demonstrated restored dystrophin expression after differentiation into cardiomyocytes and skeletal muscle as well as in vivo mice transplantation [51]. 
Table 3. List of key studies using iPSCs for gene correction in case of muscular dystrophies.

\begin{tabular}{|c|c|c|c|c|c|}
\hline Gene Based Therapy & Delivery System & Cell Type & Application & Year & Reference \\
\hline $\begin{array}{l}\text { Human Artificial Chromosome } \\
\text { (HAC) carrying dystrophin } \\
\text { sequence }\end{array}$ & $\begin{array}{l}\text { Microcelle-mediated } \\
\text { chromosome transfer }\end{array}$ & DMD-iPSC & Gene correction in DMD iPSC & 2010 & Kazuki et al. [47] \\
\hline Antisense oligonucleotide (AON) & $\begin{array}{l}\text { Polyethylenimine (PEI) } \\
\text { transfection }\end{array}$ & $\begin{array}{c}\text { DMD-iPSC cardiomyocytes } \\
\text { (7 types) }\end{array}$ & $\begin{array}{l}\text { Exon skipping in DMD to restore } \\
\text { dystrophin expression }\end{array}$ & 2013 & Dick et al. [48] \\
\hline Micro-utrophin $(\mu \mathrm{UTRN})$ delivery & $\begin{array}{l}\text { "sleeping beauty" } \\
\text { transposon system }\end{array}$ & $\begin{array}{l}\text { dKO iPSCs from mouse } \\
\text { model (severely dystrophic) }\end{array}$ & $\begin{array}{l}\text { Partial expression of } \mu \mathrm{UTRN} \text { and } \\
\text { muscle stem cell engraftment for } \\
\text { functional muscle improvement }\end{array}$ & 2013 & Filareto et al. [49] \\
\hline TALEN and CRISPR/Cas9 & Electroporation & DMD-iPSC & $\begin{array}{l}\text { Comparing correction strategies: } \\
\text { exon-skipping, frame-shifting, and } \\
\text { exon knock-in }\end{array}$ & 2015 & Li et al. [50] \\
\hline CRISPR/Cas9 & Nucleofection & DMD-iPSC & $\begin{array}{l}\text { Simple deletion strategy to target } 60 \% \\
\text { of DMD mutations in patients. }\end{array}$ & 2016 & Young et al. [49] \\
\hline Single strand oligo CRISPR/Cas9 & Nucleofection & LGMD2B/2D-iPSC & $\begin{array}{l}\text { Tissue and site-specific expression of } \\
\text { dysferlin and } \alpha \text {-sarcoglycan proteins }\end{array}$ & 2016 & Turan et al. [52] \\
\hline CRISPR-Cpf1 & Nucleofection & DMD-iPSC cardiomyocytes & $\begin{array}{l}\text { Evaluate gene correction along with } \\
\text { exon-skipping strategy for dystrophin } \\
\text { restoration in cardiomyocytes. }\end{array}$ & 2017 & Zhang et al. [53] \\
\hline CRISPR/Cas9 & Nucleofection & $\begin{array}{l}\text { DMD-iPSC and 3D iPSC } \\
\text { engineered heart muscle }\end{array}$ & $\begin{array}{l}\text { Exon-skipping of mutant and } \\
\text { out-of-frame DMD exons at hotspot } \\
\text { regions }\end{array}$ & 2018 & Long et al. [54] \\
\hline
\end{tabular}


Next, seamless allele-specific correction strategies were developed using a single-stranded oligonucleotide CRISPR/Cas9-mediated approach [52]. Using LGMD2B/2D-iPSCs, the investigators used a short single-stranded oligonucleotide for homology-directed repair along with a CRISPR/Cas9 gene-editing system to enhance its targeting efficiency. This approach led to the precise and seamless correction of the specific alleles. Although the efficiency was lower compared to other targeting approaches, it was still able to correct the expression of missing proteins (dysferlin and alpha-sarcoglycan) in tissue and a site-specific manner [52].

Recently a newer version of the gene editing system, CRISPR/Cpf1, has been evaluated for gene correction in DMD iPSCs as well as in mice models [53]. By using this system along with exon-skipping or correction of the non-sense mutations in DMD iPSCs, dystrophin expression was restored, and differentiated cardiomyocytes demonstrated enhanced contractility. In addition, germline-corrected $m d x$ mice demonstrated significant improvements in muscle histology, such as restoration of dystrophin expression along with a significant reduction of fibrosis and inflammation [53]. The results demonstrated high genome-wide targeting efficiency and specificity of the CRISPR/Cpf1 for gene editing in muscular dystrophies, particularly in the case of DMD.

Finally, in another interesting report by the same group, guide RNAs were screened to identify optimal gRNAs capable of targeting conserved RNA splice sites in 12 exons in the hotspot region of DMD gene [54]. This strategy allows for the skipping of the most common mutant or out-of-frame DMD exons within or nearby mutational hotspots. As proof of concept, this approach was evaluated in iPSCs from multiple DMD patients with large deletions, point mutations, or duplications. Results proved the efficiency of this unified approach for restoring dystrophin protein expression (in iPSC-derived cardiomyocytes) within the most common types of dystrophin gene abnormalities clustered in these hotspots [54].

\section{Perspective for Therapeutic Application of iPSCs in Muscular Dystrophies}

Currently, there is no definitive cure for muscular dystrophies, and therapies mostly consist of the management of the cardiopulmonary morbidities. Treatments, such as steroids, and physical/surgical therapies for increasing range of motion and stretches are simply palliative [18]. Although iPSCs provide a promising forecast for clinical trials in the future, this technology is nowhere near to being used in practice due to two major problems: (a) variability in the generation of pure and safe populations of cells, and (b) the identification of the ideal cell type and delivery route to target different body muscles in the case of muscular dystrophies.

One major obstacle is the development of a safe and pure myogenic cell population from iPSCs. This traditionally has been done using gene-overexpression or directed differentiation using small molecules or cytokines [30,31,41,55-58]. Although both methods demonstrated promising advances in the generation of the myogenic cells from iPSCs, there are still a few major concerns. Regarding gene over-expression, the risk of insertional mutagenesis using viral vectors remains a concern. Genomic integration is needed for stable expression of the desired gene. However, it carries the risk of insertional mutagenesis and unforeseen alterations in the genome leading to side effects, such as increased risk of malignancies [59]. These risks can also be very variable due to virus copy number, cell type, and the over-expressed gene effect [60] Moreover, Lentiviruses might cause immune reactions leading to undesirable consequences, such as triggering inflammatory reactions [61]. On the other hand, for directed differentiation approaches, parallel production of unwanted and poorly differentiated cells might carry unforeseen consequences, such as the chance of tumogenesis following cell transplantation [62]. Development of more efficient myogenic induction or directed differentiation protocols along with the identification of specific markers to purify myogenic cells will eventually eliminate this obstacle, as we and others have recently reported [41,42,63].

In addition, although the use of programmable endonuclease systems, such as TALEN and CRISPR, were designed to identify and generate DNA strand breaks at the desired and specific location of the genome, there is always the risk of off-target side effects, such as indels/mutations associated 
with these systems $[64,65]$. This risk can potentially be reduced by modification of the endonucleases to enhance their binding specificity, such as using a double nickase system or modification of gRNA length in the case of CRISPR [66,67]. In addition, new and improved high-throughput sequencing and bioinformatics allow for faster whole genome screening on corrected iPSCs and will eventually help to identify safe cells for future clinical applications. Moreover, it is still not clear if these methods are able to efficiently target and correct the gene defect in muscle stem cells (satellite cells), which is critical for maintaining the longevity of the correction in the treated muscles. Therefore, more studies are warranted to solve this obstacle.

For strategies using antisense oligonucleotide $(\mathrm{AON})$ for exon-skipping, the barriers to overcome for DMD therapy include instability of chemical structures, the efficacy of drug delivery, dose-related toxicity, and the risk of off-target effects [68]. Furthermore, in vivo AON efficacy has not proven as strong as in vitro, possibly due to diffusion problems with large molecules, particularly in damaged or fibrotic tissues. However, phase 3 trial of this method for DMD has shown limited efficacy but only in patients who maintain walking ability, not in severe cases [69].

Another major problem facing the application of iPSCs for the treatment of muscular dystrophies is the route of delivery. Since most types are muscular dystrophies involving various groups of skeletal muscle in the body, local delivery through intramuscular injection is not a practical option. Therefore, systemic routes of cell delivery would be the ultimate approach. These include intra-arterial or intravenous cell delivery. Since intravenous cell delivery suffers from cell entrapment during the first passage through organs (such as the lungs) [70] and may lead to unwanted side-effects and a significant reduction in cell quantity before reaching their target muscles, the intra-arterial route has been considered in the case of systemic muscle disorders and dystrophies. In this case, desirable cells should also be able to bind to the muscle endothelium and cross the barrier toward interstitial muscle space and eventually engraft into the damaged muscle fibers.

Although promising research has been done to study the efficiency of the intra-arterial cell route in animal models of muscular dystrophies using mesoangioblasts [71,72], in the case of iPSC-derived myogenic cells, there are limited reports so far. One good example is the derivation of mesoangioblasts-like cells from human LGMD2D-iPSCs and their subsequent gene correction using lentiviral vector expressing human $\alpha$-sarcoglycan [31]. Corrected cells were then transduced to myogenic cells using MyoD expression and then transplanted into a null mouse model for $\alpha$-sarcoglycan using intra-arterial injection through femoral arteries. As proof of concept, cell engraftment was verified by time-course imaging and histology. The results indicated the ability of human iPSC-derived cells to engraft into the dystrophic muscle following intra-arterial delivery [31]. Similar results were also reported by our collaborators and ourselves regarding the intravenous and intra-arterial delivery of murine and human iPSC-derived myogenic cells into $\mathrm{dKO}$ and $m d x$ mice models $[49,73]$. Overall, these reports provide proof of concept for the ability of systemic cell delivery in mice models of muscular dystrophies. However, the efficiency of engraftment in these reports is rather low, and further investigations are warranted to identify the ideal iPSC-derived myogenic cells capable of efficient muscle engraftment following systemic cell delivery. Another important aspect of these studies should also include the investigation of potential side-effects related to systemic cell distribution, such as entrapment and seeding outside the target tissue (muscle) which has the potential for unforeseen consequences.

iPSC, along with novel gene editing technology, has brought new insights and hopes for cell-based therapies in the case of degenerative genetic disorders, such as muscular dystrophies, and it would not be implausible to witness clinical trials in the years to come using corrected iPSCs as personalized therapies for muscular dystrophies.

Supplementary Materials: The following are available online, Figure S1: Chronological development of induced pluripotent stem cells (iPSC)-based studies in the case of muscular dystrophies. Schematic image demonstrates timeline emergence of key studies using iPSCs for modeling the disease, drug screening, and gene correction in case of muscular dystrophies. 
Funding: The Darabi laboratory is partially supported by the National Institute of Arthritis and Musculoskeletal and Skin Diseases (NIAMS) of the National Institutes of Health (NIH) under award numbers 1R01AR068293 and 1R21AR071583. The content is solely the responsibility of the authors and does not necessarily represent the official views of the National Institutes of Health.

Conflicts of Interest: The authors declare no conflict of interest.

\section{References}

1. Takahashi, K.; Tanabe, K.; Ohnuki, M.; Narita, M.; Ichisaka, T.; Tomoda, K.; Yamanaka, S. Induction of pluripotent stem cells from adult human fibroblasts by defined factors. Cell 2007, 131, 861-872. [CrossRef]

2. Takahashi, K. Yamanaka induction of pluripotent stem cells from mouse embryonic and adult fibroblast cultures by defined factors. Cell 2006, 126, 663-676. [CrossRef]

3. Yu, J.; Vodyanik, M.A.; Smuga-Otto, K.; Antosiewicz-Bourget, J.; Frane, J.L.; Tian, S.; Nie, J.; Jonsdottir, G.A.; Ruotti, V.; Stewart, R.; et al. Induced pluripotent stem cell lines derived from human somatic cells. Science 2007, 318, 1917-1920. [CrossRef]

4. Kastenberg, Z.J.; Odorico, J.S. Alternative sources of pluripotency: Science, ethics, and stem cells. Transplant. Rev. 2008, 22, 215-222. [CrossRef]

5. Holm, S. Time to reconsider stem cell ethics-The importance of induced pluripotent cells. J. Med. Ethics 2008, 34, 63-64. [CrossRef]

6. de Almeida, P.E.; Ransohoff, J.D.; Nahid, A.; Wu, J.C. Immunogenicity of pluripotent stem cells and their derivatives. Circ. Res. 2013, 112, 549-561. [CrossRef]

7. Takahashi, K.; Okita, K.; Nakagawa, M.; Yamanaka, S. Induction of pluripotent stem cells from fibroblast cultures. Nat. Protoc. 2007, 2, 3081-3089. [CrossRef]

8. Fusaki, N.; Ban, H.; Nishiyama, A.; Saeki, K.; Hasegawa, M. Efficient induction of transgene-free human pluripotent stem cells using a vector based on Sendai virus, an RNA virus that does not integrate into the host genome. Proc. Jpn. Acad. Ser. B Phys. Biol. Sci. 2009, 85, 348-362. [CrossRef]

9. Soldner, F.; Hockemeyer, D.; Beard, C.; Gao, Q.; Bell, G.W.; Cook, E.G.; Hargus, G.; Blak, A.; Cooper, O.; Mitalipova, M.; et al. Parkinson's disease patient-derived induced pluripotent stem cells free of viral reprogramming factors. Cell 2009, 136, 964-977. [CrossRef]

10. Okita, K.; Nakagawa, M.; Hyenjong, H.; Ichisaka, T.; Yamanaka, S. Generation of mouse induced pluripotent stem cells without viral vectors. Science 2008, 322, 949-953. [CrossRef]

11. Gonzalez, F.; Barragan Monasterio, M.; Tiscornia, G.; Montserrat Pulido, N.; Vassena, R.; Batlle Morera, L.; Rodriguez Piza, I.; Izpisua Belmonte, J.C. Generation of mouse-induced pluripotent stem cells by transient expression of a single nonviral polycistronic vector. Proc. Natl. Acad. Sci. USA 2009, 106, 8918-8922. [CrossRef]

12. Warren, L.; Manos, P.D.; Ahfeldt, T.; Loh, Y.H.; Li, H.; Lau, F.; Ebina, W.; Mandal, P.K.; Smith, Z.D.; Meissner, A.; et al. Highly efficient reprogramming to pluripotency and directed differentiation of human cells with synthetic modified mRNA. Cell Stem Cell 2010, 7, 618-630. [CrossRef]

13. Kim, D.; Kim, C.H.; Moon, J.I.; Chung, Y.G.; Chang, M.Y.; Han, B.S.; Ko, S.; Yang, E.; Cha, K.Y.; Lanza, R.; Kim, K.S. Generation of human induced pluripotent stem cells by direct delivery of reprogramming proteins. Cell Stem Cell 2009, 4, 472-476. [CrossRef]

14. Deng, D.; Yan, C.; Pan, X.; Mahfouz, M.; Wang, J.; Zhu, J.K.; Shi, Y.; Yan, N. Structural basis for sequence-specific recognition of DNA by TAL effectors. Science 2012, 335, 720-723. [CrossRef]

15. Moscou, M.J.; Bogdanove, A.J. A simple cipher governs DNA recognition by TAL effectors. Science 2009, 326, 1501. [CrossRef]

16. Cong, L.; Ran, F.A.; Cox, D.; Lin, S.; Barretto, R.; Habib, N.; Hsu, P.D.; Wu, X.; Jiang, W.; Marraffini, L.A.; Zhang, F. Multiplex genome engineering using CRISPR/Cas systems. Science 2013, 339, 819-823. [CrossRef]

17. Mali, P.; Yang, L.; Esvelt, K.M.; Aach, J.; Guell, M.; DiCarlo, J.E.; Norville, J.E.; Church, G.M. RNA-guided human genome engineering via Cas9. Science 2013, 339, 823-826. [CrossRef]

18. Emery, A.E. The muscular dystrophies. Lancet 2002, 359, 687-695. [CrossRef]

19. Mercuri, E.; Muntoni, F. Muscular dystrophies. Lancet 2013, 381, 845-860. [CrossRef]

20. Shieh, P.B. Muscular dystrophies and other genetic myopathies. Neurol. Clin. 2013, 31, 1009-1029. [CrossRef]

21. Flanigan, K.M. Duchenne and Becker muscular dystrophies. Neurol. Clin. 2014, 32, 671-688. [CrossRef] 
22. Love, D.R.; Forrest, S.M.; Smith, T.J.; England, S.; Flint, T.; Davies, K.E.; Speer, A. Molecular analysis of Duchenne and Becker muscular dystrophies. Br. Med. Bull. 1989, 45, 659-680. [CrossRef]

23. Bulfield, G.; Siller, W.G.; Wight, P.A.; Moore, K.J. X chromosome-linked muscular dystrophy (mdx) in the mouse. Proc. Natl. Acad. Sci. USA 1984, 81, 1189-1192. [CrossRef]

24. Brinkmeyer-Langford, C.; Kornegay, J.N. Comparative genomics of X-linked muscular dystrophies: The golden retriever model. Curr. Genet. 2013, 14, 330-342. [CrossRef]

25. Selsby, J.T.; Ross, J.W.; Nonneman, D.; Hollinger, K. Porcine models of muscular dystrophy. ILAR J. 2015, 56, 116-126. [CrossRef]

26. Wells, D.J. Tracking progress: An update on animal models for Duchenne muscular dystrophy. Dis. Model Mech. 2018, 11. [CrossRef]

27. Fukada, S.; Morikawa, D.; Yamamoto, Y.; Yoshida, T.; Sumie, N.; Yamaguchi, M.; Ito, T.; Miyagoe-Suzuki, Y.; Takeda, S.; Tsujikawa, K.; et al. Genetic background affects properties of satellite cells and mdx phenotypes. Am. J. Pathol. 2010, 176, 2414-2424. [CrossRef]

28. Park, I.H.; Arora, N.; Huo, H.; Maherali, N.; Ahfeldt, T.; Shimamura, A.; Lensch, M.W.; Cowan, C.; Hochedlinger, K.; Daley, G.Q. Disease-specific induced pluripotent stem cells. Cell 2008, 134, 877-886. [CrossRef]

29. Darabi, R.; Pan, W.; Bosnakovski, D.; Baik, J.; Kyba, M.; Perlingeiro, R.C. Functional myogenic engraftment from mouse iPS cells. Stem Cell Rev. 2011, 7, 948-957. [CrossRef]

30. Darabi, R.; Arpke, R.W.; Irion, S.; Dimos, J.T.; Grskovic, M.; Kyba, M.; Perlingeiro, R.C. Human ES- and iPS-derived myogenic progenitors restore DYSTROPHIN and improve contractility upon transplantation in dystrophic mice. Cell Stem Cell 2012, 10, 610-619. [CrossRef]

31. Tedesco, F.S.; Gerli, M.F.; Perani, L.; Benedetti, S.; Ungaro, F.; Cassano, M.; Antonini, S.; Tagliafico, E.; Artusi, V.; Longa, E.; et al. Transplantation of genetically corrected human iPSC-derived progenitors in mice with limb-girdle muscular dystrophy. Sci Transl. Med. 2012, 4, 140ra89. [CrossRef]

32. Snider, L.; Geng, L.N.; Lemmers, R.J.; Kyba, M.; Ware, C.B.; Nelson, A.M.; Tawil, R.; Filippova, G.N.; van der Maarel, S.M.; Tapscott, S.J.; et al. Facioscapulohumeral dystrophy: Incomplete suppression of a retrotransposed gene. PLoS Genet. 2010, 6, e1001181. [CrossRef]

33. Du, J.; Campau, E.; Soragni, E.; Jespersen, C.; Gottesfeld, J.M. Length-dependent CTG.CAG triplet-repeat expansion in myotonic dystrophy patient-derived induced pluripotent stem cells. Hum. Mol. Genet. 2013, 22, 5276-5287. [CrossRef]

34. Shoji, E.; Sakurai, H.; Nishino, T.; Nakahata, T.; Heike, T.; Awaya, T.; Fujii, N.; Manabe, Y.; Matsuo, M.; Sehara-Fujisawa, A. Early pathogenesis of Duchenne muscular dystrophy modelled in patient-derived human induced pluripotent stem cells. Sci. Rep. 2015, 5, 12831. [CrossRef]

35. Lin, B.; Li, Y.; Han, L.; Kaplan, A.D.; Ao, Y.; Kalra, S.; Bett, G.C.; Rasmusson, R.L.; Denning, C.; Yang, L. Modeling and study of the mechanism of dilated cardiomyopathy using induced pluripotent stem cells derived from individuals with Duchenne muscular dystrophy. Dis. Model Mech. 2015, 8, 457-466. [CrossRef]

36. El-Battrawy, I.; Zhao, Z.; Lan, H.; Li, X.; Yucel, G.; Lang, S.; Sattler, K.; Schunemann, J.D.; Zimmermann, W.H.; Cyganek, L.; et al. Ion channel dysfunctions in dilated cardiomyopathy in limb-girdle muscular dystrophy. Circ. Genom. Precis. Med. 2018, 11, e001893. [CrossRef]

37. Choi, I.Y.; Lim, H.; Estrellas, K.; Mula, J.; Cohen, T.V.; Zhang, Y.; Donnelly, C.J.; Richard, J.P.; Kim, Y.J.; Kim, H.; et al. Concordant but varied phenotypes among Duchenne muscular dystrophy patient-specific myoblasts derived using a human iPSC-based model. Cell Rep. 2016, 15, 2301-2312. [CrossRef]

38. Maffioletti, S.M.; Sarcar, S.; Henderson, A.B.H.; Mannhardt, I.; Pinton, L.; Moyle, L.A.; Steele-Stallard, H.; Cappellari, O.; Wells, K.E.; Ferrari, G.; et al. Three-dimensional human iPSC-derived artificial skeletal muscles model muscular dystrophies and enable multilineage tissue engineering. Cell Rep. 2018, 23, 899-908. [CrossRef] [PubMed]

39. Xu, B.; Magli, A.; Anugrah, Y.; Koester, S.J.; Perlingeiro, R.C.R.; Shen, W. Nanotopography-responsive myotube alignment and orientation as a sensitive phenotypic biomarker for Duchenne muscular dystrophy. Biomaterials 2018, 183, 54-66. [CrossRef]

40. Yokoo, N.; Baba, S.; Kaichi, S.; Niwa, A.; Mima, T.; Doi, H.; Yamanaka, S.; Nakahata, T.; Heike, T. The effects of cardioactive drugs on cardiomyocytes derived from human induced pluripotent stem cells. Biochem. Biophys. Res. Commun. 2009, 387, 482-488. [CrossRef] 
41. Hicks, M.R.; Hiserodt, J.; Paras, K.; Fujiwara, W.; Eskin, A.; Jan, M.; Xi, H.; Young, C.S.; Evseenko, D.; Nelson, S.F.; et al. ERBB3 and NGFR mark a distinct skeletal muscle progenitor cell in human development and hPSCs. Nat. Cell Biol. 2018, 20, 46-57. [CrossRef] [PubMed]

42. Wu, J.; Matthias, N.; Lo, J.; Ortiz-Vitali, J.L.; Shieh, A.W.; Wang, S.H.; Darabi, R. A myogenic double-reporter human pluripotent stem cell line allows prospective isolation of skeletal muscle progenitors. Cell Rep. 2018, 25, 1966-1981. [CrossRef]

43. Abujarour, R.; Bennett, M.; Valamehr, B.; Lee, T.T.; Robinson, M.; Robbins, D.; Le, T.; Lai, K.; Flynn, P. Myogenic differentiation of muscular dystrophy-specific induced pluripotent stem cells for use in drug discovery. Stem Cells Transl. Med. 2014, 3, 149-160. [CrossRef]

44. Afzal, M.Z.; Reiter, M.; Gastonguay, C.; McGivern, J.V.; Guan, X.; Ge, Z.D.; Mack, D.L.; Childers, M.K.; Ebert, A.D.; Strande, J.L. Nicorandil, a nitric oxide donor and ATP-sensitive potassium channel opener, protects against dystrophin-deficient cardiomyopathy. J. Cardiovasc. Pharmacol. Ther. 2016, 21, 549-562. [CrossRef] [PubMed]

45. Uchimura, T.; Otomo, J.; Sato, M.; Sakurai, H. A human iPS cell myogenic differentiation system permitting high-throughput drug screening. Stem Cell Res. 2017, 25, 98-106. [CrossRef]

46. Mondragon-Gonzalez, R.; Perlingeiro, R.C.R. Recapitulating muscle disease phenotypes with myotonic dystrophy 1 induced pluripotent stem cells: A tool for disease modeling and drug discovery. Dis. Model Mech. 2018, 11. [CrossRef] [PubMed]

47. Kazuki, Y.; Hiratsuka, M.; Takiguchi, M.; Osaki, M.; Kajitani, N.; Hoshiya, H.; Hiramatsu, K.; Yoshino, T.; Kazuki, K.; Ishihara, C.; et al. Complete genetic correction of ips cells from Duchenne muscular dystrophy. Mol. Ther. 2010, 18, 386-393. [CrossRef]

48. Dick, E.; Kalra, S.; Anderson, D.; George, V.; Ritson, M.; Laval, S.; Barresi, R.; Aartsma-Rus, A.; Lochmuller, H.; Denning, C. Exon skipping and gene transfer restore dystrophin expression in hiPSC-cardiomyocytes harbouring DMD mutations. Stem Cells Dev. 2013. [CrossRef]

49. Filareto, A.; Parker, S.; Darabi, R.; Borges, L.; Iacovino, M.; Schaaf, T.; Mayerhofer, T.; Chamberlain, J.S.; Ervasti, J.M.; McIvor, R.S. An ex vivo gene therapy approach to treat muscular dystrophy using inducible pluripotent stem cells. Nat. Commun. 2013, 4, 1549. [CrossRef]

50. Li, H.L.; Fujimoto, N.; Sasakawa, N.; Shirai, S.; Ohkame, T.; Sakuma, T.; Tanaka, M.; Amano, N.; Watanabe, A.; Sakurai, H.; et al. Precise correction of the dystrophin gene in duchenne muscular dystrophy patient induced pluripotent stem cells by TALEN and CRISPR-Cas9. Stem Cell Rep. 2015, 4, 143-154. [CrossRef]

51. Young, C.S.; Hicks, M.R.; Ermolova, N.V.; Nakano, H.; Jan, M.; Younesi, S.; Karumbayaram, S.; Kumagai-Cresse, C.; Wang, D.; Zack, J.A.; et al. A single CRISPR-Cas9 deletion strategy that targets the majority of DMD patients restores dystrophin function in hiPSC-derived muscle cells. Cell Stem Cell 2016, 18, 533-540. [CrossRef] [PubMed]

52. Turan, S.; Farruggio, A.P.; Srifa, W.; Day, J.W.; Calos, M.P. Precise correction of disease mutations in induced pluripotent stem cells derived from patients with limb girdle muscular dystrophy. Mol. Ther. 2016, 24, 685-696. [CrossRef] [PubMed]

53. Zhang, Y.; Long, C.; Li, H.; McAnally, J.R.; Baskin, K.K.; Shelton, J.M.; Bassel-Duby, R.; Olson, E.N. CRISPR-Cpf1 correction of muscular dystrophy mutations in human cardiomyocytes and mice. Sci. Adv. 2017, 3, e1602814. [CrossRef] [PubMed]

54. Long, C.; Li, H.; Tiburcy, M.; Rodriguez-Caycedo, C.; Kyrychenko, V.; Zhou, H.; Zhang, Y.; Min, Y.L.; Shelton, J.M.; Mammen, P.P.A.; et al. Correction of diverse muscular dystrophy mutations in human engineered heart muscle by single-site genome editing. Sci. Adv. 2018, 4, eaap9004. [CrossRef] [PubMed]

55. Borchin, B.; Chen, J.; Barberi, T. Derivation and FACS-mediated purification of PAX3+/PAX7+ skeletal muscle precursors from human pluripotent stem cells. Stem Cell Rep. 2013, 1, 620-631. [CrossRef] [PubMed]

56. Chal, J.; Oginuma, M.; Al Tanoury, Z.; Gobert, B.; Sumara, O.; Hick, A.; Bousson, F.; Zidouni, Y.; Mursch, C.; Moncuquet, P.; et al. Differentiation of pluripotent stem cells to muscle fiber to model Duchenne muscular dystrophy. Nat. Biotechnol. 2015, 33, 962-969. [CrossRef]

57. Shelton, M.; Metz, J.; Liu, J.; Carpenedo, R.L.; Demers, S.P.; Stanford, W.L.; Skerjanc, I.S. Derivation and expansion of PAX7-positive muscle progenitors from human and mouse embryonic stem cells. Stem Cell Rep. 2014, 3, 516-529. [CrossRef] 
58. Tanaka, A.; Woltjen, K.; Miyake, K.; Hotta, A.; Ikeya, M.; Yamamoto, T.; Nishino, T.; Shoji, E.; Sehara-Fujisawa, A.; Manabe, Y.; et al. Efficient and reproducible myogenic differentiation from human iPS cells: Prospects for modeling miyoshi myopathy in vitro. PLoS ONE 2013, 8, e61540. [CrossRef]

59. Hacein-Bey-Abina, S.; Garrigue, A.; Wang, G.P.; Soulier, J.; Lim, A.; Morillon, E.; Clappier, E.; Caccavelli, L. Insertional oncogenesis in 4 patients after retrovirus-mediated gene therapy of SCID-X1. J. Clin. Investig. 2008, 118, 3132-3142. [CrossRef]

60. Matrai, J.; Chuah, M.K.; VandenDriessche, T. Recent advances in lentiviral vector development and applications. Mol. Ther. 2010, 18, 477-490. [CrossRef]

61. Brown, B.D.; Sitia, G.; Annoni, A.; Hauben, E.; Sergi, L.S.; Zingale, A.; Roncarolo, M.G.; Guidotti, L.G.; Naldini, L. In vivo administration of lentiviral vectors triggers a type I interferon response that restricts hepatocyte gene transfer and promotes vector clearance. Blood 2007, 109, 2797-2805. [CrossRef] [PubMed]

62. Kim, J.; Magli, A.; Chan, S.S.K.; Oliveira, V.K.P.; Wu, J.; Darabi, R.; Kyba, M.; Perlingeiro, R.C.R. Expansion and purification are critical for the therapeutic application of pluripotent stem cell-derived myogenic progenitors. Stem Cell Rep. 2017, 9, 12-22. [CrossRef] [PubMed]

63. Magli, A.; Incitti, T.; Kiley, J.; Swanson, S.A.; Darabi, R.; Rinaldi, F.; Selvaraj, S.; Yamamoto, A.; Tolar, J.; Yuan, C. PAX7 Targets, CD54, integrin $\alpha 9 \beta 1$, and SDC2, allow isolation of human ESC/iPSC-derived myogenic progenitors. Cell Rep. 2017, 19, 2867-2877. [CrossRef] [PubMed]

64. Fu, Y.; Foden, J.A.; Khayter, C.; Maeder, M.L.; Reyon, D.; Joung, J.K.; Sander, J.D. High-frequency off-target mutagenesis induced by CRISPR-Cas nucleases in human cells. Nat. Biotechnol. 2013, 31, 822-826. [CrossRef] [PubMed]

65. Pattanayak, V.; Ramirez, C.L.; Joung, J.K.; Liu, D.R. Revealing off-target cleavage specificities of zinc-finger nucleases by in vitro selection. Nat. Methods 2011, 8, 765-770. [CrossRef] [PubMed]

66. Fu, Y.; Sander, J.D.; Reyon, D.; Cascio, V.M.; Joung, J.K. Improving CRISPR-Cas nuclease specificity using truncated guide RNAs. Nat. Biotechnol. 2014, 32, 279-284. [CrossRef] [PubMed]

67. Ran, F.A.; Hsu, P.D.; Lin, C.Y.; Gootenberg, J.S.; Konermann, S.; Trevino, A.E.; Scott, D.A.; Inoue, A.; Matoba, S.; Zhang, Y.; et al. Double nicking by RNA-guided CRISPR Cas9 for enhanced genome editing specificity. Cell 2013, 154, 1380-1389. [CrossRef]

68. Chi, X.; Gatti, P.; Papoian, T. Safety of antisense oligonucleotide and siRNA-based therapeutics. Drug Discov. Today 2017, 22, 823-833. [CrossRef]

69. McDonald, C.M.; Campbell, C.; Torricelli, R.E.; Finkel, R.S.; Flanigan, K.M.; Goemans, N.; Heydemann, P.; Kaminska, A.; Kirschner, J.; Muntoni, F.; et al. Ataluren in patients with nonsense mutation Duchenne muscular dystrophy (ACT DMD): A multicentre, randomised, double-blind, placebo-controlled, phase 3 trial. Lancet 2017, 390, 1489-1498. [CrossRef]

70. Fischer, U.M.; Harting, M.T.; Jimenez, F.; Monzon-Posadas, W.O.; Xue, H.; Savitz, S.I.; Laine, G.A.; Cox, C.S., Jr. Pulmonary passage is a major obstacle for intravenous stem cell delivery: The pulmonary first-pass effect. Stem Cells Dev. 2009, 18, 683-692. [CrossRef]

71. Sampaolesi, M.; Blot, S.; D'Antona, G.; Granger, N.; Tonlorenzi, R.; Innocenzi, A.; Mognol, P.; Thibaud, J.L.; Galvez, B.G.; Barthelemy, I.; et al. Mesoangioblast stem cells ameliorate muscle function in dystrophic dogs. Nature 2006, 444, 574-579. [CrossRef]

72. Sampaolesi, M.; Torrente, Y.; Innocenzi, A.; Tonlorenzi, R.; D’Antona, G.; Pellegrino, M.A.; Barresi, R.; Bresolin, N.; De Angelis, M.G.; Campbell, K.P.; et al. Cell therapy of alpha-sarcoglycan null dystrophic mice through intra-arterial delivery of mesoangioblasts. Science 2003, 301, 487-492. [CrossRef]

73. Matthias, N.; Hunt, S.D.; Wu, J.; Darabi, R. Skeletal muscle perfusion and stem cell delivery in muscle disorders using intra-femoral artery canulation in mice. Exp. Cell Res. 2015, 339, 103-111. [CrossRef]

(C) 2019 by the authors. Licensee MDPI, Basel, Switzerland. This article is an open access article distributed under the terms and conditions of the Creative Commons Attribution (CC BY) license (http:/ / creativecommons.org/licenses/by/4.0/). 